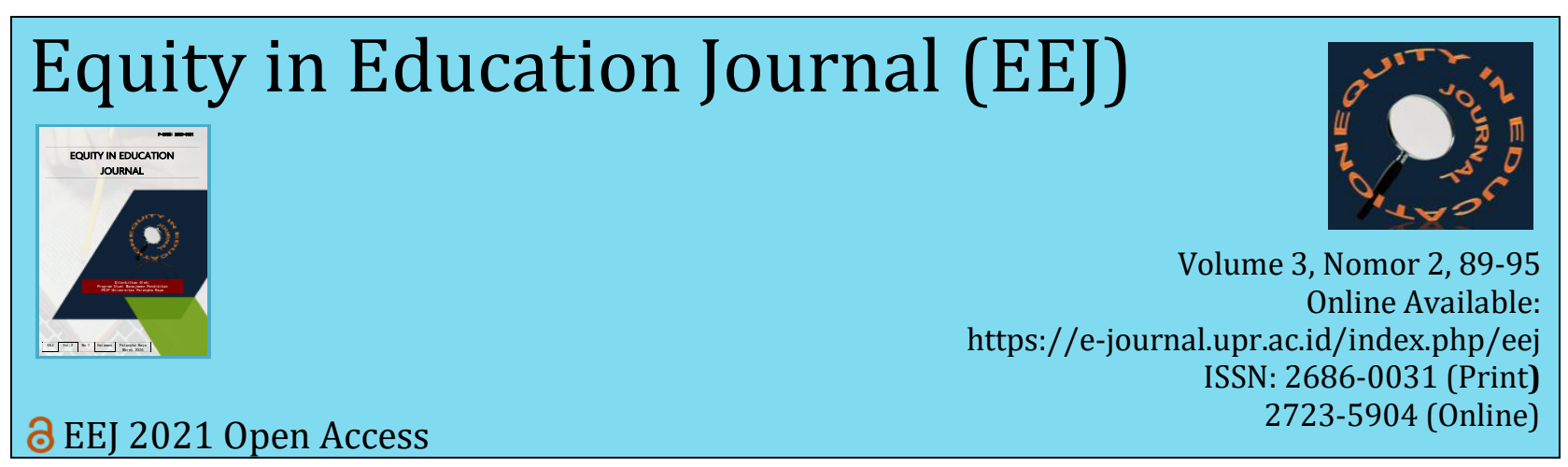

\title{
PELAKSANAAN PENGUATAN PENDIDIKAN KARAKTER (PPK) DI MASA PANDEMI COVID 19 PADA SMKN-1 PALANGKA RAYA
}

\author{
Sumarnie*, Setiawan, Riko \\ FKIP, Universitas Palangka Raya, Palangka Raya
}

\begin{abstract}
Info Artikel
Abstrak

Riwayat Artikel:

Diterima: 11 Mei 2021

Direvisi: 21 September 2021

Disetujui: 26 September 2021

Kata Kunci:

Pelaksanaan, Penguatan

Pendidikan Karakter, Pandemi

Covid 19, SMKN-1 Palangka

Raya.

Penelitian ini bertujuan mendeskripsikan Pelaksanaan penguatan pendidikan karakter di masa pandemi covid 19 pada SMKN-1 Palangka Raya mulai dari perencanaan, pelaksanaan sampai evaluasi. Metode penelitian menggunakan deskriptif kualitatif dari sumber data primer dan sekunder. Teknik pengumpulan antara lain, teknik wawancara, observasi dan analisis studi dokumen. Hasil penelitian pada Perencanaan Penguatan Pendidikan karakter sudah sudah cukup baik terintegrasi dengan mata pelajaran serta melalukan sosialiasi kepada orang tua dan peserta didik. Pelaksanaan penguatan Pendidikan karakter secara daring pada saat pembelajaran berlangsung, kegiatan kokurikuler dan ektrakurikuler, kurang efektif pada masa pandemi covid-19 karena tidak dilaksanakan secara langsung. Evaluasi pelaksanaan penguatan pendidikan karakter sudah cukup baik untuk mengukur ketercapaian pembelajaran dan penguatan pendidikan karakter. Diharapkan pendidik terus meningkatkan bimbingan dan dukungan pada peserta didik terutama aspek nilai agama dan moral sehingga peserta memiliki karakter akhlak yang mulia serta karakter moral yang kuat.
\end{abstract}

\begin{tabular}{l}
\hline Korespondensi: \\
\hline Sumarnie* \\
FKIP, Universitas Palangka \\
Raya \\
E-mail: \\
sumarnietagab@gmail.com
\end{tabular}

This study aims to describe the implementation of strengthening character education during the COVID-19 pandemic at SMKN-1 Palangka Raya starting from planning, implementation to evaluation. The research method uses descriptive qualitative from primary and secondary data sources. The collection techniques include interview, observation and document study analysis. The results of the research on the Planning for Strengthening Character Education have been quite well integrated with subjects and through socialization to parents and students. The implementation of strengthening online character education during learning, co-curricular and extracurricular activities, is less effective during the COVID-19 pandemic because it is not carried out directly. Evaluation of the implementation of strengthening character education is good enough to measure learning achievement and strengthening character education. It is hoped that educators will continue to improve guidance and support for students, especially aspects of religious and moral values so that participants have noble character and strong moral character.

\section{PENDAHULUAN}

Saat ini bangsa Indonesia bahkan dunia sedang dihadapkan pada ujian pandemi Covid-19 yang menata ulang berbagai dimensi kehidupan, terutama sektor pendidikan, kesehatan dan ekonomi. Untuk itu bangsa ini membutuhkan generasi unggul yang mampu menjadi problem solver dan dapat menjadi pemecah kebuntuan berbagai sektor kehidupan yang stagnan bahkan mengalami kemunduran. Kita semua harus berani membuat terobosan, inovasi dengan metode-metode dan 
strategi-strategi baru, dengan jiwa entrepreneurship yang berwawasan sains dan teknologi, namun berkarya secara terukur dan sejalan dengan aturan-aturan yang ada.

Kebijakan Pemerintah Pusat dan Provinsi Kalimantan Tengah yaitu pelaksanaan Pendidikan pada masa darurat penyebaran Covid-19, yaitu Belajar Dari Rumah (Learning from Home) sangat tepat untuk mencegah penyebaran Covid-19 di lingkungan sekolah, namun dari berbagai informasi media cetak, dan elektronik menyatakan implementasinya masih beragam di lapangan serta ada beberapa isu yang menyatakan bahwa pelaksanaan program penguatan pendidikan karakter di sekolah juga tidak efektif. Sedangkan pendidikan karakter bagi peserta didik sangat penting dan dalam Peraturan Presiden Nomor 87 Tahun 2017 tentang Penguatan Pendidikan Karakter dalam Pasal 3 disebutkan bahwa: "Penguatan Pendidikan Karakter (PPK) dilaksanakan dengan menerapkan nilai-nilai Pancasila dalam pendidikan karakter terutama meiliputi nilai-nilai religius, jujur, toleran, disiplin, bekerja keras, kreatif mandiri, demokratis, rasa ingin tahu, semangat kebangsaan, cinta tanah air, menghargai prestasi, komunikatif, cinta damai, gemar membaca, peduli lingkungan, peduli sosial, dan bertanggungjawab".

Kondisi Riil pada saat pademi Covid 19 semua sekolah melaksanakan pembelajaran daring sehingga pelaksanaan penguatan pendidikan karakter dikhawatirkan tidak dapat dilaksankan secara optimal, pemerintah pusat dan daerah mengharapkan semua sekolah melakukan inovasiinovasi dalam rangka pelaksanaan pendidikan karakter bagi peserta didik.

Di era teknologi saat ini muncul berbagai tatanan baru, ukuran-ukuran baru, dan kebutuhan-kebutuhan baru yang berbeda dengan sebelumnya. Hal tersebut menimbulkan konsekuensi tantangan baru dalam pendidikan nasional. Selain itu berbagai persoalan moral, budi pekerti, watak atau karakter antara lain: meningkatnya dekandensi moral, meningkatnya ketidakjujuran pelajar, dan masih tingginya kasus tindakan kekerasan yang terjadi antar pelajar seperti bullying dan tawuran serta berbagai fenomena lain yang menunjukan bahwa Indonesia telah mengalami krisis moral.

Dalam Kamus Bahasa Indonesia (2008) karakter didefinisikan sebagai: "Tabiat, sifat-sifat kejiwaan, akhlak atau budi pekerti yang membedakan seseorang dengan yang lain, dan watak. Karakter juga bisa berarti huruf, angka, ruang, simbol khusus yang dapat dimunculkan pada layar dengan papan ketik". Orang berkarakter berarti orang yang berkepribadian, berperilaku, bersifat, bertabiat, atau berwatak. Sementara istilah karakter dalam American Dictionary of the English Languange (dalam Agus Wibowo, 2013) didefinisikan sebagai kualitas-kualitas yang teguh dan khusus yang dibangun dalam kehidupan seseorang yang menentukan responnya tanpa pengaruh dengan kondisi-kondisi yang ada.

Menurut Kementerian Pendidikan Nasional (2011) dalam buku panduan pelaksanaan pendidikan karakter menyatakan bahwa: "Pendidikan karakter bertujuan mengembangkan nilainilai yang membentuk karakter bangsa, yaitu Pancasila, meliputi: (1) mengembangkan potensi peserta didik agar menjadi manusia berhati baik, berpikiran baik, dan berprilaku baik; (2) membangun bangsa yang berkarakter Pancasila; (3) mengembangkan potensi warga negara agar memiliki sikap percaya diri, bangga pada bangsa dan negaranya serta mencintai umat manusia".

Selanjutnya Kemdikbud (2016) menyatakan Gerakan PPK dapat dimaknai sebagai pengejawantahan Gerakan Revolusi Mental sekaligus bagian integral Nawacita. Gerakan PPK menempatkan pendidikan karakter sebagai dimensi terdalam atau inti pendidikan nasional sehingga pendidikan karakter menjadi poros pelaksanaan pendidikan dasar dan menengah. Lebih lanjut, gerakan PPK perlu mengintegrasikan, memperdalam, memperluas, dan sekaligus menyelaraskan berbagai program dan kegiatan pendidikan karakter yang sudah dilaksanakan sampai sekarang.

Pendapat Kemendikbud (2016) menyatakan bahwa dalam konteks yang lebih luas, penguatan Pendidikan karakter memiliki tujuan sebagai berikut: (a) Mengembangkan platform pendidikan nasional yang meletakkan makna dan nilai karakter sebagai jiwa atau generator utama penyelenggaraan pendidikan, (b) Membangun dan membekali Generasi Emas Indonesia 2045 menghadapi dinamika perubahan di masa depan dengan keterampilan abad 21, (c) 
Mengembalikan Pendidikan karakter sebagai ruh dan fondasi pendidikan melalui harmonisasi olah hati (etik dan spiritual), olah rasa (estetik), olah pikir (literasi dan numerasi), dan olah raga (kinestetik), (d) Merevitalisasi dan memperkuat kapasitas ekosistem pendidikan (kepala sekolah, guru, siswa, pengawas, dan komite sekolah) untuk mendukung perluasan implementasi pendidikan karakter, (e) Membangun jejaring pelibatan masyarakat (publik) sebagai sumbersumber belajar di dalam dan di luar sekolah, dan (f) Melestarikan kebudayaan dan jati diri bangsa Indonesia dalam mendukung Gerakan Nasional Revolusi Mental (GNRM).

Dalam Peraturan Presiden Nomor 87 Tahun (2017) tentang Penguatan Pendidikan Karakter yang disebutkan dalam Pasal 1 bahwasanya Penguatan Pendidikan Karakter yang selanjutnya disingkat PPK adalah: Gerakan pendidikan di bawah tanggung jawab satuan pendidikan untuk memperkuat karakter peserta didik melalui harmonisasi olah hati, olah rasa, olah pikir, dan olah raga dengan pelibatan dan kerja sama antara satuan pendidikan, keluarga, dan masyarakat sebagai bagian dari Gerakan Nasional Revolusi Mental (GNRM). Penguatan Pendidikan Karakter hadir dengan pertimbangan bahwa dalam rangka mewujudkan bangsa yang berbudaya melalui penguatan nilai-nilai religius, jujur, toleran, disiplin, bekerja keras, kreatif, mandiri, demokratis, rasa ingin tahu, semangat kebangsaan, cinta tanah air.

Selain itu, menurut Akbar (dalam Usman \& Raharjo, 2012) penelitian yang dilakukan di Harvard University Amerika Serikat menunjukkan bahwa kesuksesan seseorang tidak ditentukan semata-mata oleh pengetahuan dan kemampuan teknis (hard skill) saja, tetapi lebih oleh kemampuan mengelola diri dan orang lain (soft skill). Penelitian tersebut mengungkapkan, kesuksesan hanya ditentukan sekitar 20 persen oleh hard skill dan sisanya 80 persen oleh soft skill. Hal ini menunjukan kesuksesan seseorang didasari oleh kemampuan soft skill yang memadai. Pendidikan karakter sebenarnya bukan sebuah kebijakan baru. Pendidikan budi pekerti dan pendidikan budaya dan karakter bangsa merupakan berbagai kebijakan yang menuntut pengembangan karakter dalam proses pendidikan. Namun dalam pelaksanaannya masih kurang optimal. Hal ini disebabkan oleh berbagai faktor mulai dari penyusunan kebijakan program pendidikan karakter yang tidak berjalan dengan baik, kualitas sarana prasarana, kualitas tenaga pendidik, dan disituasi saat pandemi Covid 19 saat sekarang.

Sekolah lebih mengedepankan pencapaian akademik atau kecerdasan intelektual dan kurang memperhatikan pendidikan karakter. Hal ini dibuktikan dengan berbagai fakta yang ada di lapangan bahwasanya nilai ujian atau ulangan yang menjadi patokan utama dalam menentukan kemampuan peserta didik. Penanaman pendidikan karakter dapat melalui integrasi mata pelajaran dan berbagai program yang bertujuan untuk menanamkan berbagai nilai karakter yang sesuai dengan budaya bangsa. Kualitas tenaga pendidik merupakan salah satu hal penting dalam keberhasilan pelaksanaan pendidikan karakter. Hasil belajar dalam hal ini nilai karakter yang tertanam dalam diri peserta didik sangat ditentukan oleh integrasi tenaga pendidik dalam proses pembelajaran. Oleh karena itu kualitas tenaga pendidik yang baik sangat menentukan keberhasilan pendidikan karakter. SMKN-1 Palangka Raya adalah salah satu sekolah unggulan di Kota Palangka Raya.

Tujuan penelitian ini adalah mendeskripsikan tentang Pelaksanaan Penguatan Pendidikan Karakter dimasa Pandemi Covid 19 di SMKN-1 Palangka Raya, ditinjau dari aspek: (1) perencanaan, (2) pelaksanaan, dan (3) evaluasi.

\section{METODE}

Dalam penelitian ini peneliti bertindak sebagai instrumen sekaligus sebagai alat pengumpul data. Sedangkan alat-alat seperti kamera dapat digunakan namun fungsinya terbatas sebagai pendukung tugas peneliti sebagai instrumen. Jadi, instrumen penelitian dalam penelitian ini adalah peneliti sendiri sebaga instrument kunci (key instrument). Hal ini sejalan apa yang dikemukakan oleh Bogdan \& Biklen (dalam Sugiyono, 2008), bahwa dalam penelitian kualitatif peneliti dipandang sebagai instrumen kunci, yang berarti peneliti harus dapat menangkap rnakna, berinteraksi dengan nilai-nilai lokal yang mana hal tidak mungkin dapat dilakukan dengan 
instrumen yang lainnya. Keuntungan peneliti sebagai instrumen kunci dikarenakan sifatnya yang responsive dan adaptable. Peneliti sebagai instrumen akan dapat menekankan pada keholistikan (holistic emphasis), mengembangkan dasar pengetahuan (knowledge base expansion), kesegaran memproses (processual immediacy), dan mempunyai kesempatan untuk mengklarifikasi dan meringkas (opportunity for clarification and summarization), serta dapat memanfaatkan kesempatan untuk rnenyelidiki respon yang istirnewa atau khas (explore a typical or idiosyncratic responses).

Pendekatan dalam Penelitian ini adalah menggunakan pendekatan kualitatif. Metode kualitat if sebagai prosedur penelitian yang menghasilkan data deskriptif berupa kata-kata tertulis atau lisan dari orang-orang dan perilaku yang dapat diamati (Moleong, 2008). Selanjutnya Satori (2009) bahwa penelitian kualitatif memiliki karakteristik berikut: (1) Objektivitas berarti tidak memihak atau teguh pada fakta yang sesungguhnya; (2) Akurat artinya valid dan reliabel dalam pengukuran dan analisa; (3) Verifikasi, hasil suatu penelitian bukan sesuatu yang bersifat kekal abadi akan tetapi dapat dikonfirmasikan atau direvisi melalui penelitian lain; (4) Penjelasan yang hemat/singkat dan memiliki nilai ilmiah yang tinggi; (5) Empirisme, suatu penelitian adalah usaha mengungkap fakta yang nyata; (6) Penalaran logis, yakni merupakan proses ilmiah yang memerlukan penalaran logis; (7) Kesimpulan kondisional, yakni hasil penelitian tidak absolut, sehingga kesimpulannya juga tidak bersifat absolut melainkan kondisional melalui probabilitas tertentu.

Data yang dikumpulkan adalah data yang sesuai dengan fokus penelitian, yaitu: pelaksanaan Penguatan Pendidikan Karakter (PPK) di SMKN-1 Palangka Raya. Jenis data dalam penelitian ini dibedakan menjadi dua bagian, yaitu data primer dan data sekunder. Moleong (2008) data primer adalah dalam bentuk ucapan lisan dan prilaku manusia, sedangkan data sekunder bersumber dari tulisan-tulisan, rekaman, gambar-gambar atau foto-foto yang berhubungan dengan pelaksanaan Penguatan Pendidikan Karakter di SMKN-1 Palangka Raya.

Analisis data menggunakan pola interaktif data dari Miles \& Huberman (2008), meliputi: pengumpulan data, reduksi data, penyajian data, dan penarikan kesimpulan. Pengabsahan data menggunakan teknik triangulasi sumber dan metode.

\section{HASIL DAN PEMBAHASAN \\ Perencanaan Penguatan Pendidikan Karakter}

Perencanaan Penguatan Pendidikan karakter yang dilaksanakan setiap awal tahun pembelajaran yang terintegrasi dalam kurikulum disusun dalam Silabus dan RPP. Namun sekolah belum membentuk tim penguatan pendidikan karakter dan masih dalam proses pembentukan tim, Pada masa pandemi Covid-19 Sekolah juga mengadakan pertemuan terjadwal dengan orang tua, siswa, wali kelas dan guru bimbingan konseling (BK) untuk sosialisasi program penguatan Pendidikan Karakter Adapun target dan indikator pencapaian PPK adalah siswa memiliki nalai karakter, Nasionalis, Tanggung jawab, dan Integritas. Melalui integrasi mata pelajaran Agama, PK, PJOK, BK dan Sejarah.

Hasil temuan di atas sejalan pendapat Kurniadin \& Machali (2013) bahwa perencanaan pendidikan dapat diartikan sebagai sebuah proses yang sistemat is dalam rangka mempersiapkan kegiatan kegiatan di masa yang akan datang dalam bidang pendidikan. Dari pengertian tersebut dapat diketahui bahwa perencanaan pendidikan merupakan sebuah proses yang disusun secara sistematis berisi berbagai program yang akan dilaksanakan dimasa mendatang. Perencanaan pendidikan bertujuan agar program dapat berjalan efektif dan efisien.

Sesuai dengan Peraturan Menteri Pendidikan Nasional No 19 Tahun 2007 tentang Standar Pengelolaan, menyatakan proses perencanaan program wajib dilaksanakan. Menurut Kementerian Pendidikan Nasional (2011) bahwa program pendidikan karakter secara dokumen terintegrasi ke dalam kurikulum pada satuan pendidikan mulai dari visi, misi, tujuan, struktur dan muatan kurikulum, kalender pendidikan, silabus, rencana pelaksanaan pembelajaran (RPP). Proses 
perencanaan program sangat penting karena berfungsi sebagai dasar dalam pelaksanaan program sekolah sehingga program dapat berjalan sesuai harapan dan keinginan.

Namun sekolah belum membentuk Tim Penguatan Pendidikan Karakter yaitu dalam perencanaan program penguatan pendidikan karakter memerlukan tahapan yang harus dilaksanakan agar dalam proses internalisasi nilai karakter ke berbagai program yang telah disusun dapat berjalan maksimal. Tahapan tersebut mulai dari pembentukan tim yang menjadi penanggung jawab utama dalam pelaksanaan program penguatan pendidikan karakter. Tim PPK juga mempunyai peranan untuk mengidentifikasi berbagai potensi yang ada di sekolah yang dapat mendukung dalam berbagai program yang akan disusun. Potensi baik dalam lingkup internal sekolah maupun potensi eksternal sekolah. Potensi internal sekolah dapat berupa potensi asset budaya, keunikan sekolah, potensi sumber daya manusia, sumber pembiayaan, sarana prasarana, program pendidikan karakter yang sudah ada, dan tata kelola sekolah. Potensi eksternal sekolah dapat berupa lingkungan sosial budaya, potensi sumber daya manusia disekitar sekolah, pesanpesan moral atau kearifan lokal, dukungan para pemangku kepentingan, dan potensi sumber pembiayaan dari luar sekolah (Kemendikbud, 2016).

\section{Pelaksanaan Penguatan Pendidikan Karakter}

Pelaksanaan sebuah program tidak akan $100 \%$ berjalan mulus apalagi penguatan pendidikan karakter dilaksanakan selama masa pandemi Covid-19, artinya masih ada berbagai faktor yang menghambat proses pelaksanaannya. Dari data penelitian melalui, wawancara, dan dokumentasi dapat diketahui berbagai hambatan yang muncul dalam pelaksanaan penguatan pendidikan karakter di SMKN-1 Palangka Raya yaitu semangat dan motivasi siswa belajar secara daring menurun, Fasilitas perangkat belajar siswa kurang baik, jaringan dan kouta yang tidak memadai guru-guru kesulitan melakukan pemantauan kepada siswa secara maksimal karena sistem daring (dalam jaringan) sehingga pelaksanaan Penguatan Pendidikan Karakter di saat pandemi covid 19 dirasakan kurang efektif dan maksimal. Namun dari setiap kekurangan yang ada tentu memiliki kelebihan atau pendukung dalam pelaksanaan penguatan pendidikan karakter. Faktor pendukung tersebut diantaranya guru selalu memberikan motivasi kepada siswa, serta terjalin kolaborasi yang sangat baik antara wali kelas, guru mata pelajaran, guru Bimbingan Konseling dan orang tua siswa.

Pelaksanaan Penguatan Pendidikan karakter dimasa pandemi Covid-19 melalui integrasi mata pelajaran Agama, PK, PJOK, BK dan Sejarah yang telah disusun dalam Silabus dan RPP. Guru-guru melaksanakan PPK melalui pilihan dan metode pembelajaran: (1) pembelajaran kolaboratif yaitu peserta didik berlatih bagaimana bekerja sama menyelesaikan tugas dalam satu kelompok, (2) Presentasi yaitu peserta didik mempresentasikan hasil tugas kelompok, (3) Diskusi yaitu peserta didik secara aktif bersama teman-temannya secara berkelompok, berintegrasi secara verbal, saling bertukar pikiran dan informasi, saling mempertahankan pendapat, mengajukan usulan dan gagasan yang lebih baik, serta bersama-sama memecahkan masalah tertentu dalam pembelajaran, (4) Memanfaatkan TIK untuk pembelajaran yaitu diharapkan kemampuan peserta didik dalam menggunakan sarana TIK lebih baik, pembelajaran pun lebih efektif dan menarik fokus pada literasi digital. Pelaksanaan Penguatan Pendidikan Karakter melalui layanan bimbingan konseling yaitu Penguatan Pendidikan Karakter dilakukan secara terintegrasi melalui pendampingan siswa dalam melalui bimbingan dan konseling. Peranan guru BK tidak terfokus hanya membantu peserta didik yang bermasalah, melainkan membantu semua peserta didik dalam pengembangan ragam potensi, meliputi pengembangan aspek belajar/ akademik, karier, pribadi, dan sosial. Bimbingan dan konseling di sekolah dilaksanakan secara kolaboratif dengan para guru mata pelajaran, maupun orang tua siswa.

Berdasarkan data hasil temuan penelitian, SMKN-1 Palangka Raya melaksanakan Penguatan Pendidikan Karakter telah sesuai dengan Peraturan Presiden Nomor 87 Tahun 2017 tentang penguatan pendidikan karakter menyatakan penyelenggaraan program dibagi menjadi 3 kegiatan yang terintegrasi yaitu Intrakurikuler/Pembelajaran, kegiatan Kokurikuler/Penguatan, 
dan kegiatan ekstrakurikuler. Namun dimasa Covid 19 kegiatan kokurikuler dan ektrakurikuler tidak dapat dilaksanakan secara efektif / dan kurang maksimal.

\section{Evaluasi Penguatan Pendidikan Karakter}

Evaluasi Penguatan Pendidikan Karakter dilakukan oleh semua wali kelas dan guru pada setiap pelaksanaan belajar secara daring dimulai dari kehadiran peserta didik, kedisiplinan, keaktifan dan tanggung jawab dalam menyelesaikan tugas yang diberikan. Kepala sekolah melakukan suvervisi kepada guru-guru namun belum secara khusus melakukan supervisi pelaksanaan Penguatan Pendidikan Karakter di masa Pandemi Covid-19.

Arikunto \& Safruddin (2013) menyatakan evaluasi adalah kegiatan untuk mengumpulkan informasi tentang bekerjanya sesuatu yang selanjutnya informasi tersebut digunakan untuk menentukan alternatif yang tepat dalam mengambil suatu keputusan. Selain itu menurut Stuffebleam (dalam Aedi, 2016) mengemukakan evaluasi pendidikan yaitu "Focutional evaluation is the proses of delineating, obtaining and providing useful information for judging decision alternative". Menurut rumusan tersebut evaluasi pendidikan adalah suatu proses mendeskripsikan, mengumpulkan dan menyajikan informasi berguna untuk menetapkan alternatif keputusan.

Evaluasi penguatan pendidikan karakter (PPK) telah dilaksanakan dengan cukup baik, namun belum dibentunya tim evaluasi Penguatan Pendidikan karakter dimasa pandemik Covid 19 merumuskan instrumen penilaian keberhasilan, melakukan pengambilan data berdasarkan instrumen yang ada, melakukan proses deskripsi, analisis, dan pembahasan data yang didapatkan, kesimpulan hasil, serta tindak lanjut atau follow up oleh sekolah. Indikator untuk program PPK yang terintegrasi dalam kegiatan belajar mengajar disesuaikan dengan indikator penilaian sikap yang termuat dalam RPP. Sementara untuk Penguatan Pendidikan Karakter yang terintegrasi dalam kegiatan di luar pembelajaran, indikatornya disesuaikan dengan program-program terkait yang tertuang dalam tata tertib.

\section{SIMPULAN}

Berdasarkan hasil penelitian dan pembahasan yang telah diuraikan, dapat disimpulkan bahwa Perencanaan Penguatan Pendidikan Karakter sudah baik yang terintegrasi dengan mata pelajaran serta adanya sosialisasi kepada orang tua siswa terkait kegiatan belajar dari rumah selama pandemi Covid 19. Pelaksanaan penguatan pendidikan karakter dimasa pandemi covid 19 khususnya kegiatan kokurikuler dan ektrakurikuler tidak dapat dilaksanakan secara efektif/dan kurang maksimal ini memerlukan perhatian dari pemerintah pusat dan daerah khususnya Dinas Pendidikan Provinsi Kalimantan Tengah agar pelaksanaan kokurikuler dan ektrakurikuler dapat dilaksanakan secara efektif dan maksimal. Evaluasi pelaksanaan penguatan pendidikan karakter sudah cukup baik namun perlu adanya supervisi dari pengawas dan kepala sekolah agar dapat memberikan pendampingan solusi bagi guru-guru yang mengalami kesulitan dalam pelaksanaan proses belajar mengajar sistem daring (dalam jaringan) secara khusus pelaksanaan penguatan pendidikan karakter bagi peserta didik; sehingga pendidik terus meningkatkan bimbingan dan dukungan pada peserta didik terutama aspek nilai agama dan moral sehingga diharapkan peserta memiliki karakter akhlak yang mulia serta karakter moral yang kuat.

\section{UCAPAN TERIMA KASIH}

Ucapan terima kasih dari penulis dan tim kepada Kepala Sekolah dan Guru-guru SMKN-1 Palangka Raya, yang telah memberikan kemudahan akses serta dukungan moril selama melaksanakan penelitian, serta Tim Redaksi Equity in Education Journal (EEJ) yang telah memberikan kesempatan kami dapat memuat jurnal ini. 


\section{DAFTAR PUSTAKA}

Aedi, N. (2016). Dasar-Dasar Manajemen Pendidikan. Yogyakarta: Gosyen Publishing.

Arikunto S., \& Safruddin C. (2013). Evaluasi Program Pendidikan. Edisi Kedua. Jakarta: PT Bumi Aksara.

Kemendibud. (2016). Panduan Pembinaan dan Pengembangan Sekolah Rujukan Tingkat Sekolah Menengah Pertama. Jakarta: Direktorat Pembinaan Sekolah Menengah Pertama.

Kemendikbud. (2016). Panduan Penilaian Penguatan Pendidikan Karakter. Jakarta: Kemendikbud

Kemendikbud. (2016). Konsep dan Pedoman Penguatan Pendidikan Karakter. Jakarta: Kementerian Pendidikan dan Kebudayaan Republik Indonesia

Kemendiknas. (2011). Panduan Pendidikan Karakter. Jakarta: Pusat Kurikulum dan Kebukuan Kemendiknas.

Kemendiknas. (2011). Pedoman Pelaksanaan Pendidikan Karakter. Jakarta: Kementerian Pendidikan Nasional Badan Penelitian dan Pusat Kurikulum dan Perbukuan.

Kurniadin D., \& Machali I. (2013). Manajemen Pendidikan Konsep dan Prinsip Pengelolaan Pendidikan. Yogyakarta: Ar-Ruzz Media.

Miles, M. B., \& Huberman, A. M. (2008). Analisis Data Kualitatif: Buku Sumber tentang MetodeMetode Baru. Jakarta: UI Press.

Moleong, L. J. (2008). Metodologi Penelitian Kualitatif. Cet. XVII. Bandung: PT. Remaja Rosdakarya.

Peraturan Menteri Pendidikan Nasional Nomor 19 Tahun 2007 tentang Standar Pengelolaan Pendidikan Oleh Satuan Pendidikan Dasar dan Menengah.

Peraturan Presiden Nomor 87 Tahun 2017 tentang Penguatan Pendidikan Karakter.

Permedikbud Nomor 20 Tahun 2016 tentang Standar Kompetensi Lulusan Pendidikan Dasar dan Menengah.

Satori, D., \& Komariah, A. (2009). Metodologi Penelitian Kualitatif. Bandung: Alfabeta.

Sugiyono. (2008). Metode Penelitian Kuantitatif Kualitatif dan R\&D. Bandung: Alfabeta

Usman H., \& Raharjo, N. E. (2012). Model Pendidikan Karakter Kewirausahaan Di Sekolah Menengah Kejuruan. Yogyakarta: Jurnal Pendidikan Teknologi dan Kejuruan, 21(2), 140147. Doi: https://doi.org/10.21831/jptk.v21i2.2940.

Wibowo, A. (2013). Manajemen Pendidikan Karakter di Sekolah. Yogyakarta: Pustaka Pelajar. 